\title{
The Genesis of top management team diversity : selective turnover among top management teams in the Dutch newspaper publisher industry (1970-1994)
}

Citation for published version (APA):

Boone, C. A. J. J., van Witteloostuijn, A., van Olffen, W., \& de Brabander, B. (2003). The Genesis of top management team diversity : selective turnover among top management teams in the Dutch newspaper publisher industry (1970-1994). METEOR, Maastricht University School of Business and Economics. METEOR Research Memorandum No. 006 https://doi.org/10.26481/umamet.2003006

Document status and date:

Published: 01/01/2003

DOI:

10.26481/umamet.2003006

Document Version:

Publisher's PDF, also known as Version of record

Please check the document version of this publication:

- A submitted manuscript is the version of the article upon submission and before peer-review. There can be important differences between the submitted version and the official published version of record.

People interested in the research are advised to contact the author for the final version of the publication, or visit the DOI to the publisher's website.

- The final author version and the galley proof are versions of the publication after peer review.

- The final published version features the final layout of the paper including the volume, issue and page numbers.

Link to publication

\footnotetext{
General rights rights.

- You may freely distribute the URL identifying the publication in the public portal. please follow below link for the End User Agreement:

www.umlib.nl/taverne-license

Take down policy

If you believe that this document breaches copyright please contact us at:

repository@maastrichtuniversity.nl

providing details and we will investigate your claim.
}

Copyright and moral rights for the publications made accessible in the public portal are retained by the authors and/or other copyright owners and it is a condition of accessing publications that users recognise and abide by the legal requirements associated with these

- Users may download and print one copy of any publication from the public portal for the purpose of private study or research.

- You may not further distribute the material or use it for any profit-making activity or commercial gain

If the publication is distributed under the terms of Article $25 \mathrm{fa}$ of the Dutch Copyright Act, indicated by the "Taverne" license above, 


\title{
THE GENESIS OF TOP MANAGEMENT TEAM DIVERSITY \\ Selective Turnover among Top Management Teams in the Dutch \\ Newspaper Publisher Industry (1970-1994)*
}

\author{
Christophe Boone \\ (University of Antwerpen) \\ Woody van Olffen \\ (University of Maastricht) \\ Arjen van Witteloostuijn \\ (University of Durham and University of Groningen) \\ Bert De Brabander \\ (University of Antwerpen)
}

February 2003

* This research was supported by a grant from the Dutch Organization for Scientific Research (NWO) and from the Maastricht research school of Economics of TEchnology and ORganizations (METEOR) of the University of Maastricht. We thank the participants of the top management team workshop at the second European Academy of Management Conference in Stockholm (May 2002) for their useful comments. We gratefully acknowledge the data management efforts of Joyce Wicherts, Charlotte Rekko and Jacqueline Pennings. Special thanks goes to Robert van Well and Walter Hendriks for data collection. 


\section{ABSTRACT}

This paper develops and tests a model explaining diversity within top executive management teams from the perspective of selective turnover. We draw on two theoretical perspectives to describe the pull toward team homogenization (low diversity) and the push toward team heterogenization (high diversity). Schneider's attraction-selection-attrition (ASA) model is used to explain the team's natural tendency to 'hire likes and fire unlikes' (so-called homosocial reproduction), provided it has the power to do so. Rational-economic theory, however, suggests firm-specific countervailing imperatives pulling a team toward heterogeneity in order to cope with the requirements of the environment. We propose that the cycle of homosocial reproduction only gets interrupted when the teams face a compelling need for diversity, particularly when organizational performance is poor, diversification is high and competition is tough, but that the reproduction cycle is maintained if the top executive management team is powerful vis-à-vis the board of directors. We test our hypotheses in a population of top executive teams of the Big Five Dutch publishers over a 25-year period. Interestingly, many of our expectations are not supported. Relating to entry, we find that poor performance and high diversification causes teams to select likes. Moreover, although more powerful teams do tend to select likes, this is even more so when competitive intensity increases. Concerning exit, we find that poor performance increases the overall likelihood of executive exit, and that dissimilar managers tend to leave first. We conclude that homosocial reproduction does occur, particularly when the organizations face conditions that at first glance require more team diversity. Apparently, top management teams tend to close ranks when environmental pressure and complexity increases.

Explanations for these findings are discussed, which point the way to new research avenues. 


\section{INTRODUCTION}

In 1983, Jeffrey Pfeffer wrote his seminal article on organizational demographics. In this paper, Pfeffer argued that organization scientists focused too much on unobservable psychological states, such as perceptions and attitudes, in explaining organizational phenomena without much notice for the more basic, structural antecedent factors, such as the objective demography of organizations. Organizational demography refers to the distribution of organizational members along any demographic trait or any set of demographic traits (Pfeffer, 1983; Haveman, 1995). The purpose of Pfeffer's contribution was to begin the development of hypotheses concerning both the causes and consequences of variations in organizational demography. A year later, Donald Hambrick and Phyllis Mason (1984) made a similar plea for studying organizational demographics at the level of the dominant coalition of organizations (i.e., their top management teams). They argued that, as an organization is a reflection of its top managers, studying the consequences of differences in the composition of top management teams is a worthwhile endeavor. Both papers were very influential in the organization sciences domain. Their importance resides in putting back the individual into the predominantly macro-level organization theory (Sørensen, 2000). On the innovative character of this approach, Carroll and Harrison (1998: 664) comment that "[o]rganizational demography is one of a few genuinely new and exciting areas of organizations research. It is also an area with potential to unify the increasingly disparate micro and macro ends of the field.”

Both papers inspired many scholars to research the proposed links empirically. When reviewing these empirical studies two conclusions can be drawn. First, although scholars have examined many dimensions of organizational demography (e.g., average and spread of tenure, gender, ethnic background and age), the unevenness or heterogeneity in the length of 
service or tenure distribution is the demographic variable of primary interest (Carroll and Harrison, 1998). Second, the overwhelming majority of studies focused on the consequences of demography on organizational outcomes, such as innovation, diversification, adaptiveness and organizational performance (for a review see Carroll and Harrison, 1998). We agree with Lawrence (1997) that in order to fully understand the consequences of organizational demography it is essential to pose the question as to the antecedents of demographic diversity, or the lack thereof, as well (see also Mittman, 1992). ${ }^{1}$ More recently, Pfeffer (1997: 87) underscored this need to look at demographics in a dynamic way as follows: "Because organizational demography is determined by the past history of the social composition of net flows into it ... understanding organizational demography requires understanding demographic composition at some initial point and the subsequent flows into and out of the organization." In other words, to understand the origins and consequences of specific differences in demographic distributions of organizations it is essential to study its metabolism, i.e., the entry and exit of (characteristics of) individuals into and out of these social aggregates.

This metabolism perspective is important because it has the potential to offer new insights into the classical tension in the social sciences between the individual human being and the social system. Specifically, studying the demographic metabolism of social organizations may help to explain the dynamics of the aggregate entity as well. On the one hand, it is essential to understand social change because replacing outgoing members by different newcomers is one important way for formal organizations to adapt their course of action (Haveman, 1995; Schneider, Smith, Taylor and Fleenor, 1998). On the other hand, the same replacement process may rather be geared towards stability of the social system, and to the perpetuation rather than adaptation of its behavior. This happens when organizations tend 
to form demographic 'clones' of themselves through strict reproduction in hiring, firing, socialization and promotion policies. In this case, outgoing members are replaced by (or molded into) relatively identical newcomers. It follows that demographic research, linking individual behavior with system dynamics, helps to build bridges between different levels of analysis.

The specific object of our present research effort is to see how demographic metabolism causes top management teams to become either homogeneous or heterogeneous. For this purpose, we analyze the characteristics of managers entering into and exiting from top management teams vis-à-vis those of incumbent managers. In so doing, this paper reports, to our knowledge, the first study in which the dynamics of demographic heterogeneity are studied systematically by simultaneously focusing on its dual constituents, i.e., the characteristics of those who enter into and those who exit from the focal top management team. We claim that, although top management teams tend to reproduce themselves in terms of demographic characteristics, a conflicting force simultaneously operates that might pull teams toward diversity. As a starting point, on the one hand, we use Schneider's (1987) Attraction-Selection-Attrition (ASA) theory as the theoretical basis for our hypotheses. This theory provides an important account of how top management teams, through so-called teamlevel 'cycles' of attraction, selection and attrition, generally tend to gravitate toward homogeneity. On the other hand, we suggest, based on rational-economic arguments, that countervailing forces at the organizational level operate that may well undermine these ASA cycles. Specifically, we propose that the cycle of homosocial reproduction cannot be sustained when top management teams face a compelling need for diversity. We hypothesize that such is the case when organizational performance is poor, diversification is high and competition is tough. So, we focus on factors both inside and outside organizations to 
understand the demographic distribution of top management teams, as advocated by Lawrence (1997). Finally, we introduce the executive team's power as a variable that may moderate the need-for-diversity effect. We will test our hypotheses using data on the dynamics of top executive management team composition of the five largest newspaper publishers in the Netherlands over the period 1970-1994.

\section{THEORETICAL BACKGROUND}

\section{Forces pulling toward homogeneity}

Theoretical exercises on the dynamics of organizational demography emphasize the tendency of a social aggregate to reproduce itself in terms of demographic composition. Pfeffer (1997: 99), for instance, observes that "[d]emography has a tendency to perpetuate itself - to use Kanter's (1977) apt phrase, to exhibit 'homosocial reproduction'.” The Attraction-SelectionAttrition (ASA) model of Benjamin Schneider (1987) provides an interesting account on the dynamics of homosocial reproduction. The original model focuses on 'soft' characteristics such as personalities and attitudes. The ASA model outlines the forces operating to restrict organizational diversity in terms of members' characteristics, producing so-called trait homogenization (Schaubroeck, Ganster and Jones, 1998). That is, organizations move toward member homogeneity because individuals are attracted to, selected by, and stay with organizations that suit their personality characteristics (Schaubroeck, Ganster and Jones, 1998). To be more precise, "the ASA cycle suggests that, first, people are differentially attracted to organizations on the basis of an organization's character and the character's manifestations in organizational structure, strategy, and culture. This proposition is consistent with research in vocational psychology and with the literature on organizational choice ... Second, through formal and informal selection strategies, organizations choose those 
individuals who are compatible with the working environment or who fit the character of the organization ... The hypothesized basis of the selection stage in the ASA model is not a new conceptualization. Barnard (1938) prescribed selecting and promoting people to executive positions who match those already in place ... People who do not fit a working environment tend to leave or 'must be relieved'. The literature on turnover has consistently supported this hypothesis" (Schneider, Smith, Taylor and Fleenor, 1998: 463). So, organizations tend to develop a modal personality. Importantly, this ASA cycle is presumed to lead to homogeneity especially at the upper management level of organizations (Schneider, Smith, Taylor and Fleenor, 1998).

Recent empirical findings support the ASA model's central proposition that organizations are relatively homogeneous with respect to the personality of their members (Schaubroeck, Gangster and Jones, 1998; Schneider, Smith, Taylor and Fleenor, 1998). For instance, Schneider, Smith, Taylor and Fleenor (1998) used the Myers-Briggs Type Indicator to assess the personality of almost 13,000 managers from 142 organizations. Their key finding is that a substantial part of variation can be explained by organizational membership. Unfortunately, the empirical research on the ASA model to date does not shed light on the exact causes of the observed homogeneity. Is it the psychological need to be similar to others with whom one works that drives the ASA process or is it generated by situational pressures, or both (Lawrence, 1997)?

Important for the present study is that this stream of research suggests "that employers tend to replace organizational members with people who are similar to themselves" (Lawrence, 1997: 18). This extends to include demographic similarity. Westphal and Zajac (1995) and Zajac and Westphal (1996) provide at least three plausible reasons for this. First, there is ample evidence that similarity on whatever salient dimension enhances 
interpersonal attraction. This is known as the similarity-attraction principle. Second, according to self-categorization theory people derive higher self-esteem and strengthened self-identity from perceived group membership. That is, "[g]iven that demographic similarity provides a salient basis for group membership, people may favor (e.g., prefer to hire) demographically similar individuals. Alternatively, people may seek to construct or maintain homogeneous groups in order to increase the salience of group membership, thus maintaining or enhancing their self-esteem and identity" (Westphal and Zajac, 1995: 61). Apart from these two social psychological mechanisms, there are also sociopolitical reasons as to why top managers might prefer to work with demographically similar individuals. That is, hiring and promoting people who are similar, for instance because they have the same functional background or share the same strategic preferences, helps to perpetuate and institutionalize managerial power. In addition, similarity facilitates communication within the team, and diminishes the likelihood of conflict and power struggles (Pfeffer, 1983; Boone, van Olffen and van Witteloostuijn, 1998). A final reason for recruiting likes may be to fulfill a psychological need for stability and to reduce behavioral uncertainty in the work environment. Then, hiring similar others serves to enhance the perceived predictability of their behavior and thus of the working environment.

Westphal and Zajac (1995) apply these ideas to the board of director selection process, hypothesizing that the extent to which incumbent CEOs can realize their preference for demographically similar new directors depends on the relative power of the CEO vis-à-vis the board of directors. They test several hypotheses on a sample of 413 Fortune/Forbes 500 companies from 1986 to 1991. Consistent with their arguments they found that: "(1) when incumbent CEOs are more powerful than their boards of directors, new directors are likely to be demographically similar to the firm's CEO; (2) when boards are more powerful than their 
CEOs, new directors resemble the existing board; and (3) greater demographic similarity between the CEO and the board is likely to result in more generous CEO compensation contracts" (Westphal and Zajac, 1995: 60). These ideas of Westphal and Zajac can also be applied in the context of the present study, i.e., the selection of new executive managers into top management teams. This brings us to

Proposition 1: Top executive management teams tend to selectively hire and fire to the effect that their own demographic characteristics are strengthened (social reproduction).

Proposition 2: The more powerful the top executive management team is vis-à-vis the board of directors, the more forcefully homosocial reproduction operates.

\section{Forces pulling toward heterogeneity}

To date, to our knowledge, there is no direct statistical evidence concerning the consequences of homosocial reproduction for organizational effectiveness. However, Schneider, Smith, Taylor and Fleenor (1998: 468) speculate that "[o]n the issue of organizational effectiveness, however, threads from the more qualitative results of extensive case studies presented earlier by Argyris (1958) and later by Schein (1992), combined with research in the groups literature (Guzzo and Shea, 1992; Herriot and Pemberton, 1995), create a fabric suggestive of the potential importance of the modal personality construct. In all of the citations, heterogeneity was found to yield increased adaptability and flexibility in dealing with difficult tasks involving demands for creativity and innovation. In other words, as predicted by Schneider (1987), it can be inferred that (a) organizations tend toward homogeneity of personality and (b) homogeneity of personality is not beneficial to long-term organizational effectiveness." 
Why is organizational or team heterogeneity potentially so important for organizational effectiveness? Indications for this can be found in small group research. Specifically, the effects of group variety on group behavior and outcomes have been discussed in depth in many social and cognitive psychological studies (Boone, van Olffen and van Witteloostuijn, 1998). According to the notion of requisite variety (Weick, 1979), within-team diversity must be matched with the complexity and non-routineness of the decision environment to perform well (Milliken and Martins, 1996). When a group faces a complex and non-routine decision environment, team performance may benefit from having a wide range of viewpoints, which can be discussed and evaluated critically to arrive at appropriate solutions. High team diversity is likely to facilitate the production of such a wide spectrum of perspectives. As people are the carriers of cognitive capacities and as there are limits to the cognitive complexity any single individual can handle (Cyert and March, 1963), every team member can provide only part of the diversity needed to solve the problem. Varying individual cognitive resources must therefore be pooled to form diverse teams in order to solve complex problems. In this respect, demographic heterogeneity can be regarded as a "proxy for cognitive heterogeneity, representing innovativeness, problem-solving abilities, creativity, diversity of information sources and perspectives, openness to change and willingness to challenge and be challenged" (Finkelstein and Hambrick, 1996: 125). Empirical research indeed reveals that in solving complex and non-routine problems groups are more effective when composed of members with a variety of skills, knowledge, abilities and perspectives (Shaw, 1976). This is particularly evident in innovative activity (Bantel and Jackson, 1989).

So, the research above suggests that in complex and dynamic environments there are compelling rational-economic reasons for organizations to interrupt the homogenization 
processes caused by ASA cycles. As Schaubroek, Ganster and Jones (1998) put it, there is a continuous conflict between the need for diversity and the ASA processes of homogenization. We argue that as long as the process of internal team homogenization does not hamper obtaining favorable external environmental selection outcomes, homosocial reproduction is sustainable. We therefore expect that the interruption only occurs when the need for diversity is very compelling. This line of argument produces

\section{Proposition 3: The demographic reproductive selection processes at the top} management team level are more likely to be interrupted if the need for diversity is high.

Combining the power and diversity arguments, suggests an interaction effect. That is, even in the face of a need for diversity, very powerful top management teams may tend to resist the need-for-diversity forces that work against their reproductive tendencies. This gives

Proposition 4: A more powerful top executive management team, vis-à-vis the board of directors, is more likely to resist the need for diversity.

In this paper, we content that this need for team diversity is higher under any of the following three circumstances: low performance, high diversification and tough competition. We will briefly elaborate on each of these conditions below.

- Concerning organizational performance, it is clear that the urge to try something new and to change the course of action increases when performance is low. This observation follows immediately from the literature on organizational decline and turnaround strategies (van Witteloostuijn, 1998). For example, Boeker and Goodstein (1991: 805) indeed observe in a sample of 290 hospitals that "hospitals change the composition of their board to adapt to changing environmental contingencies but that the hospitals' performance moderates the rate of their response, with poorer 
performers being more willing to initiate changes in board composition than strong performers." Similarly, as team diversity is assumed to be associated with willingness and openness to change (Finkelstein and Hambrick, 1996), we expect that poor performance, which triggers a need for change, will stimulate hiring more dissimilar managers and/or preventing dissimilar managers from leaving the team, partly because team reproduction is hard to sustain vis-à-vis important organizational stakeholders when performance is low.

- Relating to diversification strategies, the general idea is that complex strategies require a broader pool of managerial knowledge and capabilities than relatively simple strategies. This line of argument is reflected in the finding in small group research that team performance is particularly enhanced by compositional diversity if groups face complex and non-routine tasks (Jehn, Northcraft and Neale, 1999; Pelled, Eisenhardt and Yin, 1999). Therefore, we expect that companies that diversify away from their core business face a need to increase top executive management team diversity in order to be able to successfully implement the diversification strategy (cf. the principle of requisite variety) (Wiersema and Bantel, 1992).

- Regarding to competitive intensity, we expect that a higher extent of competition for scarce resources will increase a team's need for diversity, acting as a countervailing force to the 'natural' tendency toward homogenization. In this context, it is useful to refer to the field of evolutionary biology in which several mechanisms are described that increase the genetic variation of a biological species. One such mechanism is called 'gene flow' (Ricklefs, 1979; Templeton, 2002). Gene flow sometimes occurs when new organisms enter a population by migration from another population. If they 
mate within the population, the genetic variation of the gene pool of that species is increased. As this out-breeding increases variation, it tends to increase the adaptive capacity and thus the survival chances of a species. This is especially important when the competitive pressure for resources is high. Analogously, we expect that top management teams tend to 'out-breed' and increase their 'genetic' variation (i.e., their diversity) when competition is tough in order to preserve or increase the survival chances of the organization. In the area of organizational learning, similar arguments have been explored, suggesting a positive correlation between intra-organizational ecological processes of variation and selection on the one hand and organizational learning performance on the other hand, particularly in turbulent environments (Burgelman, 1991 and 1994; Herriot and Pemberton, 1995).

Together, the above suggests

Proposition 5: The need for top management team diversity increases if the organization (a) faces poor organizational performance, (b) pursues a high diversification strategy and (c) fights against tough competition.

\section{HYPOTHESES}

Before we formulate our hypotheses, it is important to point to an important methodological problem that precludes studying selective entry into versus exit out of a team in the same way. Specifically, although our executive management team data allow us to observe the team from which an individual left we cannot observe the pool of candidates from which an entrant was chosen into a team. Therefore, with regard to entry, on the one hand, we can only hypothesize on the result of a selective entry process under different predefined circumstances, as an indirect indication of the nature of the underlying selection process. 
With regard to exit, on the other hand, we can hypothesize directly on selective exit as we do observe which individual is 'selected out' from the team and which is not. For these reasons, we specify separate hypotheses for selective entry and selective exit, respectively.

\section{Selective entry}

Based upon our propositions, we can derive hypotheses on two main effects and one interaction effect with regard to the top executive management team entry process. For one, top management teams tend to reproduce their demographic characteristics (Proposition 1). However, a first prerequisite of any type of reproduction is the top teams' power to do so, i.e., to actually decide on candidates (Proposition 2). We therefore expect that the extent to which top executive management teams select demographically similar newcomers does increase with their organizational power, which depends on the power base of the top executive team vis-⿳亠丷⿵冂-vis the board of directors. This is

Hypothesis 1: The higher the top executive management team power vis-à-vis the board of directors, the greater will be the demographic similarity of entrant to incumbent executives.

The direct effect of an increased need for diversity on demographic similarity is captured in the next hypothesis, which is a translation of Propositions 3 and 5 for the executive entry case. If entry were the result of a strictly rational process, following the diversity requirements of the environment, we would expect

Hypothesis 2: The higher the need for diversity [(a) poor organizational performance, (b) high diversification and (c) tough competition], the smaller will be the demographic similarity of entrant to incumbent top executives. 
The process of selective entry of dissimilar members in the face of a need for diversity is likely to be moderated by the power of the executive team (Proposition 4). Specifically, we expect that the rationality argument will be counterbalanced by the power effect. Even if pressures for diversity mount, that is, powerful teams will resist the need for increased diversity, and will rather try to reproduce their own demographic characteristics. We therefore qualify Hypothesis 2 by suggesting

Hypothesis 3: The higher the need for diversity [(a) poor organizational performance, (b) high diversification and (c) tough competition], the smaller will be the demographic similarity of entrant to incumbent top executives, especially when top executive management team power vis-à-vis the board of directors is low.

\section{Selective exit}

Concerning the exit process, individuals who do not fit the team tend to leave or 'must be relieved', as summarized in Proposition 1. Remember that, unlike for the entry process, we can now compare each and every team member's demographic similarity to the rest of the team, and thus study the impact on the probability of exit. In other words, we can now directly observe the phenomenon of interest. That is,

Hypothesis 4: The higher an individual executive's demographic dissimilarity to the top executive management team, the higher is her or his likelihood of exit from the team.

Building on this, Proposition 2 to 5's interaction arguments can be added. First, following homosocial reproduction theory, we expect executive team homogeneity to be larger with a powerful top executive management team. That is, a powerful team will seek to 
'facilitate' the process of exclusion of dissimilar members. As a result, team power moderates the impact of demographic distance on the likelihood of team exit, which gives

Hypothesis 5: The larger the top executive management team power vis-à-vis the board of directors, the higher the likelihood that a demographically dissimilar executive will exit from the team.

Second, the ASA-driven expulsion of 'the dissimilar' from the team will be interrupted on rational grounds if the need for diversity in a team is high. In other words, we expect that the need for diversity variables will moderate the impact of demographic distance on the exit rate. From this, we formulate

Hypothesis 6: The higher the need for diversity [(a) poor organizational performance, (b) high diversification and (c) tough competition], the lower the likelihood that a demographically dissimilar executive will exit from the team.

Third, we expect the reinforcing effect of top executive management team power (Hypothesis 5) to produce an internal counter-force against the external need for diversity (Hypothesis 6). This implies the following three-way interaction

Hypothesis 7: The higher the need for diversity [(a) poor organizational performance, (b) high diversification and (c) tough competition], the lower the likelihood that a demographically dissimilar executive will exit from the team, especially when top executive management team power vis-à-vis the board of directors is low.

\section{METHODOLOGY}

Data 
The hypotheses are tested on data collected from the five largest independent newspaper publishers in the Netherlands, in particular NDU/Reed-Elsevier, Perscombinatie, De Telegraaf, $V N U$ and Wegener. The time window of observation covers 25 years: the period from 1970 to 1994. Data on the independent publisher NDU pertain to the period 1970-1978, when it was taken over by Reed Elsevier, entering the Dutch newspaper market in 1979 . The five companies existing after 1978 are referred to as the 'Big Five'. This results in data on $125(=5 * 25)$ year/team combinations. We collected organization-level variables on the one hand and information on the composition of the top executive management team and board of directors on the other hand. The organization-level (financial) data come from the yearly annual accounts of the companies. The demographic information on members of the executive management team and board of directors was obtained from multiple sources, including the annual accounts, membership lists of NDP (the professional association of newspaper editors), editions of Who is who in the Netherlands?, and personnel archives of the publishing companies.

\section{Models}

Two types of models will be estimated to test our hypotheses. First, we will model the entry process by looking at the demographic characteristics of the new executive managers compared to their incumbent counterparts. In this case, the dependent variable is a distance measure of the demographic characteristics of the entrant vis-à-vis those of the incumbents, which will be recorded each time an entry is observed (Westphal and Zajac, 1995). Second, the exit process will be modeled at the individual manager level of analysis. This is possible because we can now observe those who do and those who do not exit at each moment in time. 
We use event-history analysis to model the exit event as a function of the demographic distance of the focal manager compared to his or her incumbent colleagues.

The dependent variable in the event-history framework is the instantaneous rate of exit from the top executive management team, which is defined as

$$
r(t)=\lim _{d t \rightarrow 0} \frac{\operatorname{Pr}(\text { exit } t, t+d t \mid \text { no exit by } t)}{d t}
$$

where $\operatorname{Pr}($.$) is the probability of a manager experiencing exit from the team between t+d t$, conditional on being at risk for the event at $t$. Note that in the present case duration $t$ represents the team tenure of a manager. The specific rate models we estimate are piecewise constant-rate exponential models of the general form

$$
r(t)=\exp \left(\alpha_{l}+A \alpha\right)
$$

where $\alpha_{l}$ is a constant coefficient associated with the $l$ th tenure period. $A$ is a row vector of covariates, and $\alpha$ is an associated vector of coefficients assumed not to vary across time periods (Blossfeld and Rohwer, 1995; Carroll and Hannan, 2000). The piecewise constantrate model is useful because no specific assumptions are made about the age (in this case, tenure) dependence of the exit process. Exit rates are specified as log-linear functions of the covariates, so estimated failure rates are constrained to be positive. Because the covariates vary over time, team histories were split into yearly intervals and covariates updated at the beginning of each interval. Time-varying covariates imply repeated observations of the same 
subject. As a result, the assumption of independence of the observations is highly questionable, meaning that the conventional estimate of the variance-covariance matrix of the coefficients (and, hence, the standard errors) is not appropriate. Therefore, the significance of the estimated coefficients will be evaluated by means of robust standard errors based on the Huber/White/sandwich estimator of variance, which takes the clustering of observations into account. We used STATA (version 6.0) to estimate the vector of parameters by the method of maximum likelihood. 


\section{Operationalization}

Based on board membership lists and additional data gathered 'on site', we could record all executive entrants to a team in a given year, as well as all executives leaving a team. During the 25-year observation period 1970-1994, the top management teams of the Big Five publishing companies were populated by 66 different executives. ${ }^{2}$ The total number of manager/year observations is 458 . The average size of a management team was about 4.31 executives $(\mathrm{sd}=1.40)$. A total of 46 new entrants and 45 exiting managers were recorded. After screening for missing (demographic) values this resulted in an effective data set for analysis comprising of 40 entrants and 40 exiters. On average, a team experienced a mutation (i.e., either an exit or entry event) every 1.5 years. Figure 1 shows the exact numbers of entrants into and exiters from the Big Five executive management teams over time.

\section{[Insert Figure 1 about here]}

Note that entry and exit are quite evenly spread over time, and that the entry and exit patterns tend to follow up on each other as replacement of executives occurs.

Overall demographic distance of entrants and exiters to the incumbent team members was assessed by means of four demographic characteristics, one being continuous and three categorical in nature. The continuous demographic variable is the executives' age. As usual (e.g., Westphal and Zajac, 1995), demographic distance or dissimilarity to the team of a focal individual $i$ on this variable is the mean squared Euclidean distance to every single incumbent team member $j$, following

$$
\sqrt{\sum\left(X_{i}-X_{j}\right)^{2} /(n-1)} .
$$


Three dichotomous categorical variables were recorded: career path, industry experience and academic status. $\underline{\text { Career path }}$ refers to whether the individual made a career within the company (1) or was attracted from outside the organization (0). Industry experience relates to previous experience $(>3$ years $)$ within the publishing industry $(1=$ yes and $0=$ no). Finally, academic status measures whether the individual possessed a university degree (1) or not (0). To calculate the extent of similarity of the focal individual $i$ with the rest of the team on these three characteristics, we used Blau's index, here defined as the squared proportion of team members with the same background. To render this a measure of dissimilarity as well, this squared proportion was subtracted from 1.

All four distance measures thus assess an individual's dissimilarity to the rest of the team. These dissimilarities were calculated for all executive management team members, both migrants and incumbents. In order to obtain a single general proxy of how far out an individual found itself, on average, from the rest of the team (s)he was entering or leaving, we standardized each single measure and calculated the average of the four individual distance measures. This general distance measure will be the focal variable in our analyses below. Note that we decided to use such an overall distance measure for substantive reasons. Specifically, Priem, Lyon and Dess (1999: 941) correctly observed that "changing a top management's demographic profile typically involves replacing one or more members of the TMT, but such changes do not affect the group uniformly along every demographic dimension. ... Thus, replacing one or more TMT members likely will not affect all demographic variables uniformly; a new member may increase tenure heterogeneity, decrease age heterogeneity, leave functional heterogeneity unchanged, and so on, within the TMT." This implies that the distance of a manager vis-⿳亠丷⿵冂-vis the other team members can best 
be assessed by cumulating (uncorrelated) distances along several dimensions. In other words, for our purposes distance is best operationalized as an additive measure.

According to the so-called strategic contingencies theory of intra-organizational power, members of or groups in an organization derive power from being able to deal with the critical issues that the organization faces (Hickson, Hinings, Lee, Schneck and Pennings, 1971; Hambrick, 1981). This ability depends on the saliency and extent of resources the individual or group can contribute to tackle these contingencies. In a managerial context, it is clear that information and expertise are major sources of power, because both provide decision makers with the necessary ammunition for sound decision making. Especially with respect to the publisher industry, it has been noted that effective managerial functioning requires a thorough understanding of the ins and outs of the publisher business (Powell, 1990). This is because many operations in such knowledge-intensive industries are based on network relationships and personal linkages (Pennings, Lee and van Witteloostuijn, 1998). As Powell (1990) argues, industry-specific, idiosyncratic knowledge is very important in any type of relational markets. So, management teams embodying much organizational and industry know-how are likely to be relatively powerful in the publisher industry. To assess the know-how of a manager in the present study we used the proxies of career path and industry experience as defined above. Executive managers with more than three years of industry experience who made career inside the organization are likely to be most knowledgeable. Following Westphal and Zajac (1995), we assume that power basically derives from the asymmetry of information and knowledge between the executive management team vis-à-vis the board of directors. Therefore, to obtain a measure of relative executive management team power we calculated the percentage of members originating from within the company in the management team minus the percentage of members 
originating from within the company in the board. The same procedure was followed with regard to industry experience. These two measures were standardized and summed to obtain one proxy for the executive management teams' relative power.

Organizational performance was measured as the firm's yearly gross return on sales (ROS). In order to capture firm diversification we calculated the Herfindahl index (i.e., the sum of squared proportions) on the spread of firm turnover in ten different activities, particularly newspapers, journals, books, advertisement papers, professional journals, graphical activities, sales activities, databases, television and scientific activities. Heavy reliance on a few activities (i.e., low diversification) raises the Herfindahl index. By subtracting this index from 1 , we obtained a positive measure of diversification. ${ }^{3}$ To proxy our final independent variable, firm-level competitive intensity, we subtracted each firm's yearly net turnover growth rate from that of the combined four competitors in our Big Five sample. The idea is that crowding occurs, and competitive pressures are most severely felt, when the focal company's growth figure lags behind that of the major competitors.

Finally, four control variables are taken on board. Firm size was measured as total capital invested (i.e., total assets). As we intend to explain shifts in executive management team heterogeneity resulting from entry into and exit from the team, we deemed it important to control for ex ante average team heterogeneity - that is, before (i.e., at $t$-1) the event takes place. By doing so, we assure that the initial conditions with respect to team composition are comparable across teams. The team heterogeneity measure is an average index based on the standardized dispersion values of the same four demographic variables used to measure demographic distance, i.e., team standard deviation of age, and Herfindahl indices of team industry experience, career path and academic status. In the exit analyses, we also controlled for the individual's age and tenure within the team. 


\section{RESULTS}

\section{General sample and company descriptives}

Table 1 reports the 25-year averages and standard deviations of the main descriptive variables per publisher. Publishers are ordered by decreasing size.

[Insert Table 1 about here]

All publishers experienced a steady rise in total assets, with $V N U$ traditionally being the biggest to be challenged only by $N D U$ / Elsevier from the late 1970s onward. Long-run performance (ROS) figures among the Big Five are around 10 percent, with a distinct drop for all at the beginning of the 1980s when a recession hit the Dutch economy. However, even then only one publisher recorded a loss during a single year (i.e., Wegener in 1982). The degree of diversification is generally rather high in the publishing industry. High levels of diversification are either maintained (Wegener and $V N U$ ) or developed (NDU / Elsevier and Telegraaf) over time. Only one publisher (Perscombinatie) sticks quite close to the knitting. As the yearly turnover growth figures can vary strongly over time, so does the experienced gap with major competitors (i.e., competitive intensity). Two publishers managed to be, on average, on par with competition, two were ahead and one lagged behind ( $V N U)$. Apparently, this 'number-one publisher' in terms of size $(V N U)$ has difficulty in keeping up its turnover growth rate vis-à-vis its major competitors. Note that all four competitors of $N D U$ / Elsevier experienced a maximum level of competitive intensity in the year of the $N D U$ / Elsevier merger (1979), as makes logical sense.

\section{The entry process}

The 40 entrants had an average age of 48 years $(\mathrm{sd}=6.7)$. Of these executives, 75 percent had industry experience, 60 percent held an academic degree and 58 percent were promoted 
from within the company. Table 2 summarizes the remaining descriptives, and the results from the entry analyses are shown in Table 3.

[Insert Tables 2 and 3 about here]

The dependent variable is the demographic distance of the entrant to the team. Column 1 reports main effects, whilst interactions are added one by one in Columns 2-4. Hypothesis 1 predicts that the similarity of entrants to their incumbent team members will be larger in case of more powerful executive management teams. The sign of the team power variable is negative and significant, as expected (cf. Column 1 of Table 3). As a result, Hypothesis 1 is accepted.

As far as Hypothesis 2 is concerned, we expect poor performance to have a negative effect on the entrant's distance, and diversification profile and competitive intensity to produce a positive effect. As it happens, however, we see the exact opposite pattern of results with respect to performance and diversification. Note that both coefficients are marginally significant at the 10-percent level in Model 1 of Table 3. Poor firm performance seems to lower the entrants' distance to the team (the coefficient of the performance variable becomes significant at the 5-percent level in Model 4 of Table 3). A marginally significant negative effect is found for firm diversification (cf. Column 1 of Table 3), indicating that more diversified companies hired more similar entrants (the coefficient of diversification becomes significant at the 5-percent level in Model 3 of Table 3). Competitive intensity has an insignificant effect on the entrants' distance to the team. So, we observe the tendency that executive teams of poorly performing and highly diversified organizations select likes. Overall, Hypothesis 2 must be rejected.

Finally, Hypothesis 3 predicted an interaction between team power and the need for diversity. The significance levels of the cross-product terms in Equations 2 to 4 (Table 3) 
indicate that only a sigificant interaction for team power and competitive intensity emerges. This interaction indicates that the negative effect of team power on the entrants' dissimilarity increases with competitive intensity: the higher competitive intensity, particularly the more powerful teams hire likes. ${ }^{4}$ Thus, although competitive intensity is assumed to increase the need for diversity, it in fact strengthens the negative effect team power has on the entrants' demographic distance. This runs counter to Hypothesis 3, which is therefore also rejected.

\section{The exit process}

To analyze the exit process, we compared the exiting team members with the individuals in the executive management teams they left behind (the 'incumbents') in a given year. We thus tried to predict 40 exits amid 321 incumbent team members not leaving the team at that time, adding up to 361 observations. The descriptive statistics related to the variables used in the exit analyses reported below are given in Table 4, and the results of estimating the piecewise constant-rate models predicting the hazard of exit out of the team are provided in Table $5 .^{5}$

[Insert Tables 4 and 5 about here]

We split the team tenure of the managers by trial and error in four pieces to describe the tenure dependence of the exit rate (from 0 to 3,3 to 5,5 to 10 , and more than 10). This choice is justified on the basis of careful observation of the distribution of team exits relative to tenure and model-fit comparisons with models using other 'tenure pieces'. More fine-grained splits tend to substantially reduce the goodness-of-fit statistics of the models. Each model shows that the impact of tenure on exit follows an inverted U-shape (cf. Table 5). Apparently, the exit rate first increases and is highest for managers with tenure between three and five years, and then gradually decreases again with increasing tenure. This pattern suggests an extended honeymoon period in the first part of the top executive managers' tenure. Note that 
the hazard of exit is lowest in the first three years of tenure, reflecting a kind of probation period for newcomers. As common sense would suggest, all models show a strong positive effect of a member's age: the older one gets, the higher the likelihood of leaving the team, which is partly driven by forced retirement. As far as organizational characteristics are concerned, Table 5 reveals a systematic positive impact of organizational size and a strong negative effect of profitability on the hazard rate. Executive turnover appears to be higher in large organizations. Interestingly, it decreases when publishers are performing well. Apparently, poor organizational performance boosts executive exit, either voluntary or involuntarily.

Hypothesis 4 predicts a higher hazard of exit for those members showing more distance to the executive management team. This hypothesis is clearly supported by the positive significance of the 'demographic distance' variable (cf. Column 1 of Table 5). This finding is consistent with previous research in the field (Carroll and Harrison, 1998). Contrary to Hypothesis 5, however, the distance effect does not seem to depend upon (i.e., is not moderated by) the team's organizational power base (cf. Column 2 of Table 5). Hypothesis 6 predicts a rational diminution of a team's self-reproduction rate in case of a high need for diversity. However, none of the three interaction terms is significant (cf. Columns 3-5 in Table 5). Thus, the likelihood that dissimilar members will leave the team is not lower if the need for diversity is high. Taken together, we are led to reject Hypothesis 6. Finally, we estimated models with three-way interaction effects (cf. Hypothesis 7). As none of these produced significant findings, we do not report the results here. Clearly, Hypothesis 7 had to be rejected as well.

\section{APPRAISAL}


In the present study, we set out to study whether or not executive management teams reproduce their own demographic characteristics through selective hiring and firing. We expected this process to operate provided that (a) the executive teams have enough power vis$\grave{a}$-vis the board of directors and (b) there are no compelling organizational circumstances that would render it more rational to disrupt this reproductive process, forcing the team to hire more dissimilar members. To explore these issues, we analyzed the entry and exit of individual executives to and from the top management teams of the five biggest Dutch newspaper publishers over a 25-year period. Several interesting relationships were found, although many of our hypotheses were not supported. In fact, the entry and exit processes into and out of the top executive management teams seem to follow quite another logic, at least in this sample.

Concerning the entry process, we found a marginally significant tendency that poor performance and high diversification causes executive teams to select likes, which is exactly the opposite of our prediction. In addition, although more powerful teams do select likes, this is even more so when competitive intensity increases. Concerning the exit process, we find that poor performance increases the overall likelihood of executive exit, where dissimilar managers tend to leave first. Taking together these findings, we conclude that team reproduction and homogenization do indeed occur, especially when organizations face conditions that, at first glance, theoretically require more team diversity. Apparently, top executive management teams tend to close ranks when environmental pressure and complexity increase. Why would teams want to close ranks? At least two explanations can be offered.

A first explanation has a behavioral flavor, suggesting that closing ranks might be some kind of 'threat-rigidity' response of executive management teams (Staw, Sandelands 
and Dutton, 1981). In this case, we need to recast our conceptualization of the rational drivers of the 'need for diversity' in terms of threatening circumstances to the team, rather than the organization. That is, low profitability, high competitive pressure or increased environmental diversity (i.e., diversification) might not only increase an executive team's need for diversity, but may at the same time constitute a threat for the very survival of the team. All this may cause a team to 'close ranks' by hiring 'comforting' likes and relieving 'dissimilar' managers in order to diminish uncertainty in these circumstances. Note that this explanation is consistent with research in the field of inter-group conflict, which shows that people are more likely to cooperate in a social dilemma if it is embedded in the context of inter-group conflict (for a review see Bornstein and Ben-Yossef, 1994). Our findings suggest, mutatis mutandis, that external (cf. inter-group) competitive pressure not only induces within-group cooperation, but also the 'closing of ranks'. If this explanation holds true, then executive management team metabolism is driven more by behavioral processes at the team level than by rational-economic factors at the organizational level, which opens up interesting paths for future investigations. For instance, it may be worthwhile to look at what happens to team composition in the face of very disturbing stimuli, such as performance decline crises and hostile merger bids. Does 'closing ranks' occur there as well and, if so, does it have distinct consequences for the (flexibility of the) team's behavioral repertoire and the outcomes of the decline or bid process?

A second explanation departs from the central assumption of our model and previous research that rational-economic countervailing imperatives are likely to push teams toward increasing diversity. For instance, we invoked the principle of requisite variety to underpin the benefits of diversity in certain circumstances. It is, however, possible that this assumption underestimates the process-loss disadvantages of team heterogeneity. That is, executive team 
diversity could have important drawbacks in relation to intra-group functioning, and thus might be a double-edged sword (Boone, van Olffen and van Witteloostuijn, 1998). If team members have diverging frames of reference, attitudes and values, so-called process losses might occur as intra-group communication is hampered. This, in turn, enhances the chance that conflicts, turnover and power struggles will occur, thereby reducing the operational efficiency of the team. So, maybe the closing of ranks when performance is low and complexity is high (high diversification) is not so much irrationally counterproductive, but rather an appropriate attempt of the team to master the environment. Closing ranks might increase the likelihood of effective implementation of, for instance, turnaround strategies in the face of low performance and elaborating synergies in case of high diversification. To check the plausibility of this explanation we performed a post-hoc analysis of the impact of average team heterogeneity on the return on sales of our publisher companies. If indeed we overestimated the benefits of executive management team diversity, then the relationship between heterogeneity and performance should be negative or at least non-positive. The team heterogeneity measure is the same as the corresponding control variable used in the analyses presented above. The results are reported in Table 6 .

\section{[Insert Table 6 about here]}

The fixed-effect regression estimates clearly reveal a significant negative effect of team heterogeneity at time $t-1$ on return on sales at time $t$ (cf. Table 5$)$. So, diversity does seem to hamper performance, at least in the short run, in this industry. ${ }^{6}$ Closing ranks could therefore be interpreted as a rational, though not necessarily conscious, move in the present setting. Apparently, in this industry the metabolism of the executive management team fits external selection pressures: replacing unlikes with likes (team homogenization) on the one hand and firm profitability on the other hand. Future research could investigate to what extent this is 
the case in other industries, too, in order to find out in which circumstances the selection logic at the team level is dysfunctional or functional at the organizational level.

Apart from the extensions mentioned above there are several other potential ways ahead, taking into account some of the limitations of the current study. For instance, one might have a closer look at the potentially important role of the CEO (or chairperson in the board case) of the management team to find out whose character is being reproduced: that of the 'average team member' (as in our study) or that of the CEO? Probably, personal power is likely to play a role in this process, too, as the characteristics of the CEO are more likely to be reproduced when (s)he has more power vis-à-vis the rest of the team. Another area open to future investigations focuses on the proper characteristics to study. Until now, the emphasis has been on demographic characteristics. Note, however, that these are only surrogate measures of the real underlying constructs of interest, such as personalities and beliefs. It is self-evident that comparable reproduction studies using individual personality or value measures along the lines set out by Schneider, Smith, Taylor and Fleenor (1998) would add enormously to our understanding of team metabolism processes. After all, proving that personality differences between organizations exist is one (important) thing, but showing the (metabolic) processes by which they occur is another matter. As it seems fair to assume that the make-up of the management team provides an image of that of the organization as a whole, turnover studies on management teams could shed light on such processes. But still, larger-scale studies into the demographic (or value) metabolism of higher-order social aggregates (like organizations) would offer the true 'proof of the pudding' for ASA theory. It would involve painstaking retrospective analyses of personnel records, which is often a problem due to limited data accessibility or even data unavailability. The growth of 
automated personnel management systems may however make such studies feasible in the near future.

Finally, keeping in mind the study by Schneider, Smith, Taylor and Fleenor (1998), it is not inconceivable that industry differences in the extent, operation and outcome of selective turnover processes exist as well. In other words, as we already touched upon above, the findings in this study could be sample specific. In this respect, we note that executive management team turnover in the publisher industry has been limited in the past 25 years, resulting in relatively stable teams. It might therefore be interesting to focus on industries with high team dynamics in future work. As another example, in professional industries the reproduction of core values might be (even) more prominent and important to effectiveness than in manufacturing companies. In fact, professionalization processes ('normative isomorphism', as in DiMaggio and Powell, 1983) can be conceived of as the gradual shaping of a values' blueprint that serves as a selective screening device later on. Thus, not only the shaping and perpetuation of certain values, but the comparative study of their content between industries seems a promising area for research. Whatever the future research settings, we do however think that more emphasis should be paid to the drawbacks of executive team diversity with respect to effective strategy implementation, at least as far as the short-run performance consequences are concerned. Related to this is the need to incorporate indicators of long-run performance (such as growth, survival and innovation), besides short-term profitability measures as in the present study, in future research. This is essential to be able to unravel the complicated relationship between team diversity and organizational effectiveness in the longer run. 


\section{REFERENCES}

Argyris, C. (1958) Some problems in conceptualizing organizational climate: a case study of a bank, Administrative Science Quarterly, 2, 501-520.

Bantel, K.A., and S.E. Jackson (1989) Top management and innovations in banking: does composition of the top team make a difference? Strategic Management Journal, 10, 107124.

Barnard, C.I. (1938) The Functions of the Executive, Cambridge MA: Harvard University Press.

Blossfeld, H.-P., and G. Rohwer (1995) Techniques of Event-History Modeling: new approaches to causal analysis, Mahwah, NJ: Lawrence Erlbaum.

Boeker, W., and J. Goodstein (1991) Organizational performance and adaptation: effects of environment and performance on changes in board composition, Academy of Management Journal, 34, 805-826.

Boone, C., W. van Olffen, and A. van Witteloostuijn (1998) Psychological team make-up as a determinant of economic firm performance: an experimental study, $\underline{\text { Journal of Economic }}$ Psychology, 19, 43-73.

Bornstein, G., and M. Ben-Yossef (1994) Cooperation in intergroup and single-group social dilemmas, Journal of Experimental Social Psychology, 30, 52-67.

Burgelman, R.A. (1991) Intraorganizational ecology of strategy making and organizational adaptation: theory and field research, Organization Science, 2, 239-262.

Burgelman, R.A. (1994) Fading memories: a process theory of strategic business exit in dynamic environments, Administrative Science Quarterly, 39, 24-56. 
Carroll, G.R., and J.R. Harrison (1998) Organizational demography and culture: insights from a formal model and simulation, Administrative Science Quarterly, 43, 737-667.

Carroll, G.R., and M.T. Hannan (2000) The Demography of Corporations and Industries, Princeton, NJ: Princeton University Press.

Cyert, R.M., and J.G. March (1963) A Behavioral Theory of the Firm, Englewood Cliffs NJ: Prentice Hall.

DiMaggio, P.J., and W.W. Powell (1983) The iron cage revisited: institutional isomorphism and collective rationality in organizational fields, American Sociological Review, 48, 147-160.

Finkelstein, S., and D.C. Hambrick (1996) Strategic Leadership: top executives and their effects on organizations, Minneapolis: West.

Guzzo, R.A., and G.P. Shea (1992) Group performance and intergroup relations in organizations, In M.D. Dunette and L.E. Hough (Eds.), Handbook of Industrial and Organizational Psychology, Volume 3 ( $2^{\text {nd }}$ edition), 269-313, Palo Alto, CA: Consulting Psychologists Press.

Hambrick, D.C. (1981) Environment, strategy and power within topmanagement teams, Administrative Science Quarterly, 26, 253-275.

Hambrick, D.C., and P.A. Mason (1984) Upper echelons: organizations as a reflection of its top managers, Academy of Management Review, 9, 193-206.

Haveman, H.A. (1995) The demographic metabolism of organizations: industry dynamics, turnover, and tenure distributions, Administrative Science Quarterly, 40, 586-618.

Herriot, P., and C. Pemberton (1995) Competitive Advantage through Diversity: organizational learning from difference, London: Sage. 
Hickson, D.J., C.R. Hinings, C.A. Lee, R.E. Schneck, and J.M. Pennings (1971) A strategic contingencies theory of intraorganizational power, Administrative Science Quarterly, 16, 216-229.

Jehn, K.A., G.B. Northcraft., and M.A. Neale (1999). Why differences make a difference: a field study of diversity, conflict, and performance in workgroups, Administrative Science Quarterly, 44, 741-763.

Kanter, R.M. (1977) Men and Women of the Corporation, New York: Basic Books.

Lawrence, B.S. (1997) Opening the black box of organizational demography. Organization Science, $8,1-22$.

Milliken, F.J., and L.L. Martins (1996) Searching for common threads: understanding the multiple effects of diversity in organizational groups, Academy of Management Review, $21,402-433$.

Mittman, B.S. (1992) Theoretical and methodological issues in the study of organizational demography and demographic change, Research in the Sociology of Organizations, 10 , $3-53$.

Olffen, W. van (1999) Team-Level Locus of Control and Competitive Team Behavior: an experimental study, Maastricht: Datawyse.

Pelled, L.H., K.M. Eisenhardt, K.M., and Xin (1999) Exploring the black box: an analysis of work group diversity, confict, and performance, Administrative Science Quarterly, 44, 128.

Pennings, J.M., K. Lee, and A. van Witteloostuijn (1998) Human capital, social capital, and firm dissolution, Academy of Management Journal, 41, 425-440.

Pfeffer, J. (1983) Organizational demography, Research in Organizational Behavior, 5, 299357. 
Pfeffer, J. (1997) New Directions for Organization Theory: problems and prospects, New York: Oxford University Press.

Powell, W.W. (1990) Neither market nor hierarchy: network forms of organization, Research in Organizational Behavior, 12, 295-336.

Priem, R.L., D.W. Lyon, and G.G. Dess (1999) Inherent limitations of demographic proxies in top management team heterogeneity research, Journal of Management, 25, 935-953.

Ricklefs, R.E. (1979) Ecology, New York: Chirra Press.

Schaubroek, J., D.C. Ganster, and J.R. Jones (1998) Organization and occupational influences in the Attraction-Selection-Attrition process, Journal of Applied Psychology, $83,869-891$.

Schein, E.H. (1992) Organizational Culture and Leadership (2 ${ }^{\text {nd }}$ edition), San Francisco: Jossey-Bass.

Schneider, B. (1987) The people make the place, Personnel Psychology, 40, 437-453.

Schneider, B., D.B. Smith, S. Taylor, and J. Fleenor (1998) Personality and organizations: a test of the homogeneity of personality hypothesis, Journal of Applied Psychology, 83, $462-470$.

Shaw, M.E. (1976) Group Dynamics: the psychology of small group behavior, New York: McGraw-Hill.

Sørensen, J. (2000) The ecology of organizational demography: managerial tenure distributions and organizational competition, Industrial and Corporate Change, 8, 713744.

Staw, B.M., L.E. Sandelands, and J.E. Dutton (1981) Threat-rigidity effects in organizational behavior: a multi-level analysis, Administrative Science Quarterly, 26, 501-524.

Templeton, A.R. (2002) Out of Africa again and again, Nature, 416, 45-51. 
Weick, K.E. (1979) The social psychology of organizing, MA: Addison-Wesley.

Westphal, J.D., and E.J. Zajac (1995) Who shall govern?: CEO/board power, demographic similarity, and new director selection, Administrative Science Quarterly, 40, 60-83.

Wiersema, M.G., and B.A. Bantel (1992) Top management team demography and corporate strategic change, Academy of Management Journal, 35, 91-121.

Witteloostuijn, A. van (1998) Bridging behavioral and economic theories of decline: organizational inertia, strategic competition, and chronic failure, Management Science, $44,501-519$.

Zajac, E.J., and J.D. Westphal (1996) Who shall succeed?: How CEO/board preferences and power affect the choice of new CEOs, Academy of Management Journal, 39, 64-90. 
Figure 1

Total number of Big Five team mutations

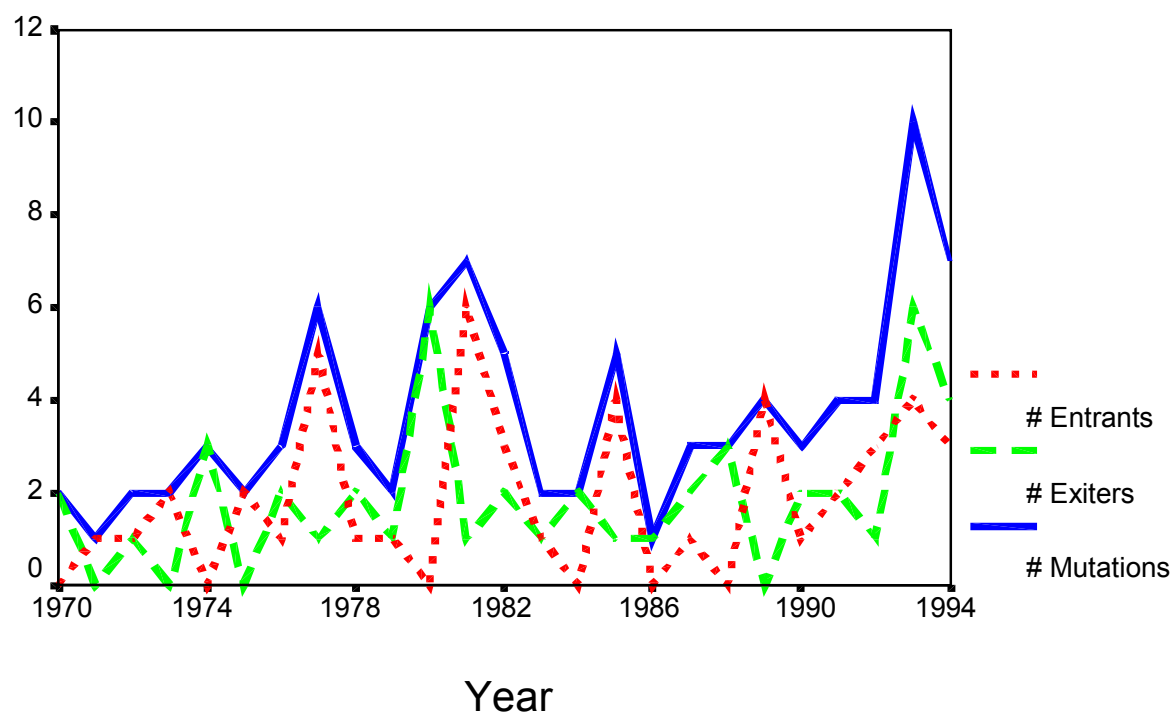


TABLE 1

Descriptives of the Big Five Dutch publishing companies

(1970-1994)

\begin{tabular}{|c|c|c|c|c|c|}
\hline $\begin{array}{c}\text { Firm } \\
\text { descriptive }\end{array}$ & Publisher & Mean & $\begin{array}{l}\text { Standard } \\
\text { deviation }\end{array}$ & $\begin{array}{l}\text { Minimum } \\
\text { (year) }\end{array}$ & $\begin{array}{c}\text { Maximum } \\
\text { (year) }\end{array}$ \\
\hline \multirow[t]{5}{*}{ Size $(* 1000$ Dfl) } & $V N U$ & 700,834 & 260,572 & $373,940(1970)$ & $1,270,815(1991)$ \\
\hline & NDU/Elsevier & 480,960 & 326,591 & $98,996(1970)$ & $1,245,681(1990)$ \\
\hline & Telegraaf & 307,174 & 233,097 & $38,954(1970)$ & 773,927 (1994) \\
\hline & Wegener & 179,850 & 151,047 & $18,942(1970)$ & $568,846(1994)$ \\
\hline & Perscombinatie & 103,439 & 52,487 & $50,193(1970)$ & 249,991 (1994) \\
\hline \multirow[t]{5}{*}{ Performance (ROS) } & $V N U$ & .10 & .02 & $.07(1982)$ & $.15(1994)$ \\
\hline & NDU/Elsevier & .10 & .05 & $.05(1975)$ & $.18(1992)$ \\
\hline & Telegraaf & .17 & .03 & $.13(1970)$ & $.25(1972)$ \\
\hline & Wegener & .09 & .04 & $-.03(1982)$ & $.14(1971)$ \\
\hline & Perscombinatie & .07 & .03 & $.00(1982)$ & $.12(1992)$ \\
\hline \multirow[t]{5}{*}{ Diversification } & $V N U$ & .74 & .07 & $.66(1976)$ & $.85(1990)$ \\
\hline & NDU/Elsevier & .65 & .14 & $.47(1971)$ & $.81(1980)$ \\
\hline & Telegraaf & .43 & .13 & $.13(1970)$ & $.53(1994)$ \\
\hline & Wegener & .63 & .02 & $.62(1988)$ & $.71(1994)$ \\
\hline & Perscombinatie & .16 & .10 & $.06(1992)$ & $.50(1993)$ \\
\hline \multirow{5}{*}{$\begin{array}{l}\text { Competitive } \\
\text { intensity }\end{array}$} & $V N U$ & .05 & .14 & $-.16(1987)$ & $.55(1979)$ \\
\hline & NDU/Elsevier & -.07 & .32 & $-1.49(1979)$ & $.16(1994)$ \\
\hline & Telegraaf & .00 & .13 & $-.36(1993)$ & .38 (1979) \\
\hline & Wegener & -.08 & .17 & $-.48(1992)$ & $.23(1979)$ \\
\hline & Perscombinatie & .00 & .17 & $-.69(1994)$ & .34 (1979) \\
\hline
\end{tabular}


TABLE 2

Descriptives of the entry process $(n=40)$

\begin{tabular}{|c|c|c|c|c|c|c|c|c|c|c|}
\hline \multirow[t]{2}{*}{ Variable } & \multirow[t]{2}{*}{ Mean } & \multirow[t]{2}{*}{ S.d. } & \multirow[t]{2}{*}{ Min. } & \multirow[t]{2}{*}{ Max. } & \multicolumn{6}{|c|}{ Correlations $^{1}$} \\
\hline & & & & & 1 & 2 & 3 & 4 & 5 & 6 \\
\hline 1. Demographic distance & .004 & .66 & -1.34 & 1.77 & - & & & & & \\
\hline 2. Team power & .11 & .77 & -1.72 & 1.44 & -.28 & - & & & & \\
\hline \multicolumn{11}{|l|}{ Need for diversity } \\
\hline 3. Firm performance & .10 & .05 & -.03 & .20 & .18 & -.00 & - & & & \\
\hline 4. Firm diversification & .57 & .20 & .11 & .84 & -.23 & .11 & .28 & - & & \\
\hline 5. Competitive intensity & -.04 & .20 & -.69 & .34 & -.01 & .12 & -.06 & .07 & - & \\
\hline \multicolumn{11}{|l|}{ Control variables } \\
\hline 6. Firm size $(* 1000$ Dfl.) & 423887 & 305033 & 58987 & 1142568 & -.06 & -.03 & $.46^{* *}$ & $.72 * * *$ & .14 & - \\
\hline 7. Team heterogeneity & -.06 & .56 & -1.42 & .92 & .20 & $-.49 * *$ & .10 & $-.52 * *$ & -.08 & -.16 \\
\hline
\end{tabular}

\footnotetext{
${ }^{1}$ One-tailed significance is reported as follows: ${ }^{*} \mathrm{p}<.05 ;{ }^{* *} \mathrm{p}<.01$; and ${ }^{* * *} \mathrm{p}<.001$
} 
TABLE 3

OLS regression analysis of entrants' demographic distance

to the incumbent team members $(n=40)^{1}$

\begin{tabular}{|c|c|c|c|c|}
\hline & 1 & 2 & 3 & 4 \\
\hline Constant & $\begin{array}{l}.42 \\
(.40)\end{array}$ & $\begin{array}{l}.41 \\
(.41)\end{array}$ & $\begin{array}{l}.45 \\
(.41)\end{array}$ & $\begin{array}{l}.32 \\
(.38)\end{array}$ \\
\hline Firm size & $\begin{array}{c}1.75 \mathrm{E}-7 \\
(5.58 \mathrm{E}-7)\end{array}$ & $\begin{array}{c}1.79 \mathrm{E}-7 \\
(5.67 \mathrm{E}-7)\end{array}$ & $\begin{array}{c}4.09 \mathrm{E}-7 \\
(6.11 \mathrm{E}-7)\end{array}$ & $\begin{array}{c}1.95 \mathrm{E}-7 \\
(5.22 \mathrm{E}-7)\end{array}$ \\
\hline Team heterogeneity & $\begin{array}{l}-.30 \\
(.31)\end{array}$ & $\begin{array}{l}-.29 \\
(.31)\end{array}$ & $\begin{array}{l}-.28 \\
(.31)\end{array}$ & $\begin{array}{l}-.22 \\
(.29)\end{array}$ \\
\hline Team power & $\begin{array}{l}-.30^{*} \\
(.16)\end{array}$ & $\begin{array}{l}-.34 \\
(.34)\end{array}$ & $\begin{array}{l}.20 \\
(.55)\end{array}$ & $\begin{array}{l}-.41^{*} \\
(.16)\end{array}$ \\
\hline$\frac{\text { Need for diversity }}{\text { - Firm performance }}$ & $\begin{array}{c}3.70 \\
(2.28)\end{array}$ & $\begin{array}{l}3.67 \\
(2.33)\end{array}$ & $\begin{array}{c}3.17 \\
(2.35)\end{array}$ & $\begin{array}{l}3.65^{*} \\
(2.13)\end{array}$ \\
\hline - Firm diversification & $\begin{array}{r}-1.46 \\
(.90)\end{array}$ & $\begin{array}{r}-1.45 \\
(.91)\end{array}$ & $\begin{array}{c}-1.56^{*} \\
(.91)\end{array}$ & $\begin{array}{l}-1.23 \\
(.84)\end{array}$ \\
\hline & $\begin{array}{l}.21 \\
(.58)\end{array}$ & $\begin{array}{l}.20 \\
(.59)\end{array}$ & $\begin{array}{l}.22 \\
(.58)\end{array}$ & $\begin{array}{l}-.41 \\
(.60)\end{array}$ \\
\hline $\begin{array}{l}\text { Interaction terms } \\
\text { - Power * Performance } \\
\text { - Power * Diversification } \\
\text { - Power * Competition }\end{array}$ & & $\begin{array}{c}.46 \\
(2.93)\end{array}$ & $\begin{array}{l}-.89 \\
(.94)\end{array}$ & $\begin{array}{c}-1.27^{*} \\
(.53)\end{array}$ \\
\hline $\mathrm{F}$ & 1.42 & 1.19 & 1.34 & $2.21 *$ \\
\hline $\mathrm{R}^{2}$ & .21 & .21 & .23 & .33 \\
\hline $\mathrm{R}^{2}$-adjusted & .06 & .03 & .06 & .18 \\
\hline
\end{tabular}

${ }^{1}$ Standard errors in parenthesis. One-tailed significance is reported as follows: ${ }^{*} \mathrm{p}<.05 ;{ }^{* *} \mathrm{p}<.01$; and $* * * \mathrm{p}<.001$. 
TABLE 4

Descriptives of the exit process $(n=361)$

\begin{tabular}{|c|c|c|c|c|c|c|c|c|c|c|c|c|c|}
\hline \multirow[t]{2}{*}{ Variable } & \multirow[t]{2}{*}{ Mean } & \multirow[t]{2}{*}{ S.d. } & \multirow[t]{2}{*}{ Min. } & \multirow[t]{2}{*}{ Max. } & \multicolumn{9}{|c|}{ Correlations $^{1}$} \\
\hline & & & & & 1 & 2 & 3 & 4 & 5 & 6 & 7 & 8 & 9 \\
\hline 1. Individual exit $(0 / 1)$ & .11 & .31 & 0 & 1 & - & & & & & & & & \\
\hline 2. Demographic distance & -.01 & .56 & -1.20 & 1.57 & .09 & - & & & & & & & \\
\hline 3. Team power & .12 & .75 & -1.74 & 1.44 & -.06 & $-.42 * * *$ & - & & & & & & \\
\hline \multicolumn{14}{|l|}{ Need for diversity } \\
\hline 4. Firm performance & .11 & .05 & -.03 & .25 & -.03 & .03 & .03 & - & & & & & \\
\hline 5. Firm diversification & .57 & .21 & .06 & .85 & -.02 & $-.45 * * *$ & $.12 *$ & .06 & - & & & & \\
\hline 6. Competitive intensity & -.005 & .22 & -1.49 & .55 & .02 & .06 & -.07 & .04 & -.10 & - & & & \\
\hline \multicolumn{14}{|l|}{$\underline{\text { Control variables }}$} \\
\hline 7. Age & 52.81 & 6.52 & 37 & 66 & $.20 * * *$ & $-.13 *$ & -.02 & $.19 * * *$ & .07 & -.01 & - & & \\
\hline 8. Tenure in team & 8.48 & 5.57 & 1 & 26 & .06 & .00 & -.00 & $.19 * * *$ & -.01 & .08 & $.38 * * *$ & - & \\
\hline 9. Firm size (*1000 Dfl.) & 454089 & 305448 & 43563 & 1270815 & .06 & $-.23 * * *$ & -.02 & $.27 * * *$ & $.72 * * *$ & .01 & $.12 *$ & $.18 * * *$ & - \\
\hline 10. Team heterogeneity & .13 & .50 & -.99 & 1.35 & .04 & $.83 * * *$ & $-.47 * * *$ & .02 & $\begin{array}{l}- \\
.42 * * * \\
\end{array}$ & -.09 & -.05 & -.00 & $.24 * * *$ \\
\hline
\end{tabular}

${ }^{1}$ One-tailed significance is reported as follows: ${ }^{*} \mathrm{p}<.05 ;{ }^{* *} \mathrm{p}<.01$; and ${ }^{* * *} \mathrm{p}<.001$. 
TABLE 5

Piecewise constant-rate exponential hazard models of individual exit from the team

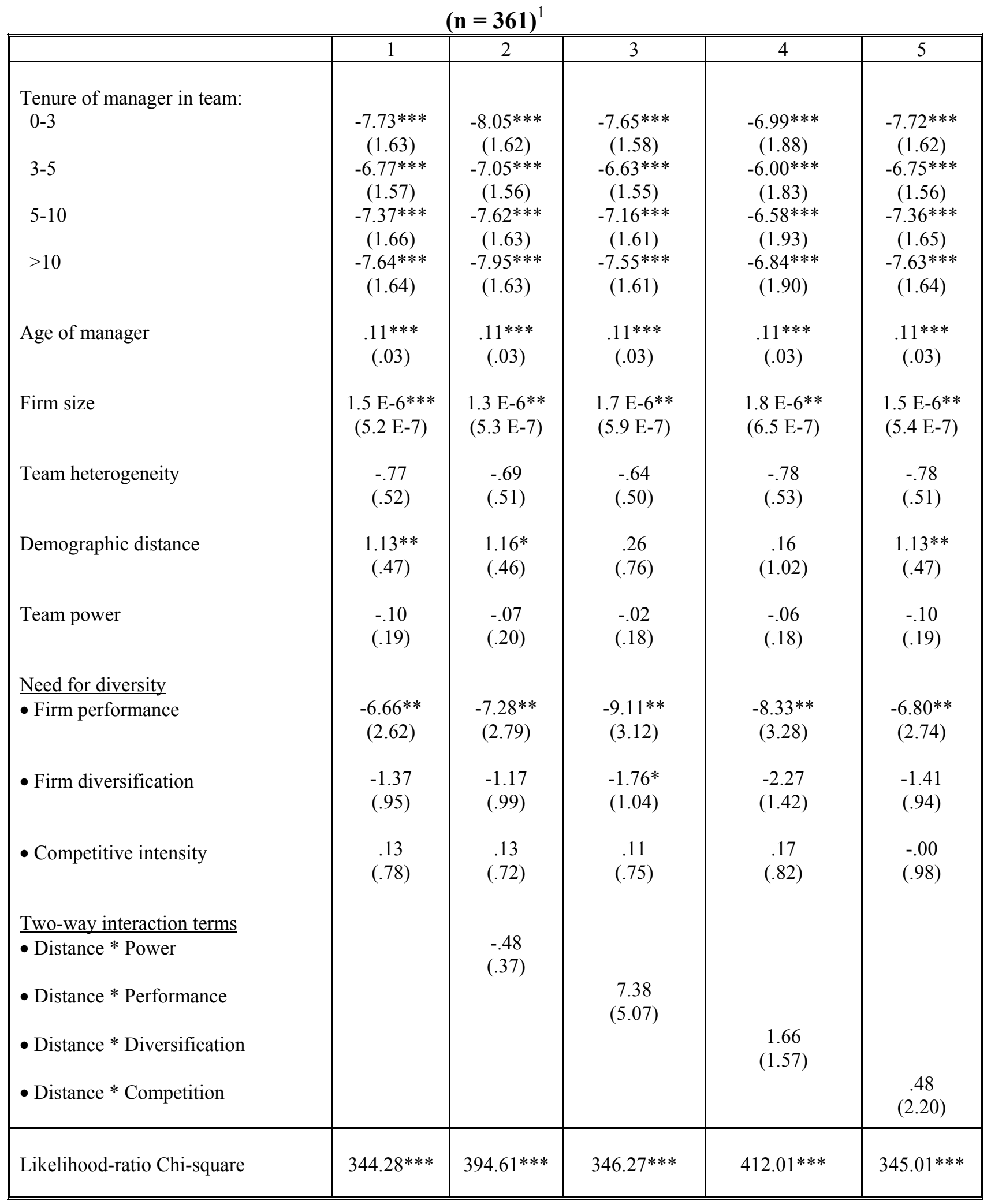

${ }^{1}$ Number of managers $=53$, number of exits $=40$ and number of spells $=361$. Standard errors in parenthesis. One-tailed significance is reported as follows: ${ }^{*} \mathrm{p}<.05 ; * * \mathrm{p}<.01$; and ${ }^{* * *} \mathrm{p}<.001$. Significance levels are based on robust standard errors (based on the Huber/White/sandwich estimator of variance) to take into account that the observations within individuals cannot be assumed to be independent. 
TABLE 6

Fixed-effect estimates of publisher return on sales $(\mathbf{n}=\mathbf{1 0 5})^{1}$

\begin{tabular}{|l|c||}
\hline Constant & $.16^{* * *}$ \\
Team heterogeneity & $(.02)$ \\
Merger & $-.02 * *$ \\
& $(.007)$ \\
Firm size & $.07 * * *$ \\
& $(.02)$ \\
Team power & $8.39 \mathrm{E}-8 * * *$ \\
& $(1.8 \mathrm{E}-8)$ \\
Firm diversification & .005 \\
& $(.004)$ \\
Competitive intensity & $-.17 * * *$ \\
& $(.04)$ \\
\hline $\mathrm{R}^{2}$ & .02 \\
\hline
\end{tabular}

\footnotetext{
${ }^{1}$ Independent variables are lagged one period except for variable Merger (1 after merger of $N D U$ with Reed Elsevier starting in 1979, and zero otherwise). Standard errors in parenthesis. One-tailed significance is reported as follows: $* \mathrm{p}<.05 ; * * \mathrm{p}<.01$; and $* * * \mathrm{p}<.001$.
} 


\section{NOTES}

${ }^{1}$ A notable exception is Haveman's interesting paper (1995), presenting an ecological model of the antecedents of organizational tenure distributions.

${ }^{2}$ The number for board members in the same period is 122 . Average board size $(7.89$ with $\mathrm{sd}=2.15)$ was almost double that of the average executive management team.

${ }^{3}$ Note that our diversification measure does not weigh for the relatedness of the ten activities. We tried to develop a weighing scheme on the basis of assessments by experts. However, both intra and inter-rater reliabilities on the extent of relatedness of the different activities turned out to be extremely low. Therefore, we decided to use a simple Herfindahl index.

${ }^{4}$ The interaction effect is monotonic, meaning that the effect of team power is negative over the full range of the competitive intensity variable.

${ }^{5}$ The exit process was also investigated using Cox proportional hazard rate models and logistic regression analysis. The results were almost identical to the ones obtained with the piecewise constant-rate specification reported below.

${ }^{6}$ Note that similar findings were found in a very different setting as well (Boone, van Olffen and van Witteloostuijn, 1998). 